\title{
Localization of Synaptotagmin-Binding Domains on Syntaxin
}

\author{
Yun Kee and Richard H. Scheller \\ Department of Molecular and Cellular Physiology, Howard Hughes Medical Institute, Stanford University Medical Center, \\ Stanford, California 94305
}

Synaptotagmin, an abundant calcium- and phospholipidbinding protein of synaptic vesicles, has been proposed to regulate neurotransmitter release at the nerve terminal. To understand better the biochemical mechanism of neurotransmitter release, we have investigated the calcium-dependent and -independent protein-protein interactions between synaptotagmin I and syntaxin 1a, a subunit of the receptor for synaptic vesicles on the presynaptic plasma membrane. Soluble syntaxin 1a binds to synaptotagmin glutathione S-transferase (GST) fusion protein, and the binding was decreased in the presence of calcium. A synaptotagmin fragment containing the second $\mathrm{C} 2$ repeat (Syt3-5) had the same binding profile as the whole cytoplasmic domain; however, fragments containing the first $\mathrm{C} 2$ repeat (Syt1-3 and Syt2-3) showed calciumdependent binding to syntaxin. In addition, the soluble fulllength cytoplasmic domain of synaptotagmin binds to a syntaxin
GST fusion protein in a calcium-dependent manner. Syntaxin domains required for calcium-dependent and -independent synaptotagmin-binding were localized using syntaxin deletion mutants. Amino acids 241-266 of the syntaxin $C$ terminus were required for calcium-independent binding of synaptotagmin. The minimal domain required for calcium-dependent binding of synaptotagmin to syntaxin was localized to amino acids $220-266$. The syntaxin domains required for synaptotagmin binding overlap with the domains for vesicle-associated membrane protein (or VAMP) and $\alpha$-soluble $N$-ethyl-maleimide-sensitive fusion protein attachment protein (or $\alpha$ SNAP) interactions. The data suggest both calcium-dependent and -independent roles of synaptotag$\mathrm{min}$ in regulating synaptic vesicle release and/or recycling.

Key words: synaptotagmin; syntaxin; $\alpha S N A P ;$ VAMP; calcium; synaptic vesicle
The regulated release of neurotramsmitlers is governed by an intricate pathway of synaptic vesicle membrane trafficking within the presynaptic nerve terminal. Although a general outline of the membrane flow within the terminal has been understood for many years, the biochemical mechanisms underlying this vesicular trafficking pathway are just beginning to emerge (for review, see Bennett and Scheller, 1994; Scheller, 1995; Südhof, 1995). Beginning with the characterization of proteins localized to the synaptic vesicles and presynaptic plasma membrane, a series of proteinprotcin interactions has bcen proposed to account for vcsiclc docking, activation, and membrane fusion (Matthew et al., 1981; Oyler et al., 1989; Bennett et al., 1992; Inoue and Akagawa, 1992; Wilson et al., 1992; Söllner et al., 1993b; Pevsner et al., 1994; Søgaard et al., 1994). Two proteins on the synaptic vesicle, vesicleassociated membrane protein (VAMP; also called synaptobrevin) and synaptotagmin, have been shown to form a complex with two proteins on the plasma membrane, synaptosome-associated protein (SNAP-25) and syntaxin (Bennett et al., 1992; Söllner et al., 1993a). This $7 \mathrm{~S}$ heterotetrameric complex is likely to represent one of the docked states of the vesicles containing neurotransmitter at the plasma membrane. After docking, the action of $\alpha$ SNAP [ $\alpha$-soluble $N$-ethyl-maleimide-sensitive fusion protein (NSF) attachment protein] and NSF ( $N$-ethyl-maleimide-sensitive factor)

\footnotetext{
Received Oct. 18, 1995; revised Dec. 18, 1995; accepted Dec. 27, 1995

We thank Thomas Schwarz for helpful comments and critical reading of this manuscript, and we thank Mark Bennett for some syntaxin deletion mutants. We also thank Jason Bock, Janice Braun, Richard Lin, and Shu-Chan Hsu for general comments and corrections on this manuscript.

Correspondence should be addressed to Richard H. Scheller, B155, Beckman Center, Howard Hughes Medical Institute, Molecular Cellular Physiology, Stanford CA 94305.

Copyright $\odot 1996$ Society for Neuroscience $0270-6474 / 96 / 161975-07 \$ 05.00 / 0$
}

is proposed to be critical for activation and final release of neurotransmitter (Söllner et al., 1993b).

Many of the molecules important for neurotransmitter release are similar to constitutive vesicle trafficking proteins, which have been found to function at other stages of the secretory pathway. Despite this similarity, the nervous system requires a specialized set of regulatory requirements so that transmitter release can precisely follow the action potential. In a very general sense, this regulation is achieved through the priming of vesicles that are docked at the plasma membrane ready to be secreted. As the action potential depolarizes the nerve terminal membrane, a specific set of ion channels allows the influx of calcium ions, which triggers membrane fusion and neurotransmitter secretion. The mechanisms that govern the calcium triggering of membrane fusion are not yet known, and the molecules involved in this process are a matter of current debate and investigation.

One of the most intensively studied proteins in the presynaptic nerve terminal is the synaptic vesicle protein synaptotagmin I. This molecule is a $65 \mathrm{kDa}$ integral membrane protein with a glycosylated amino terminus that is inside the vesicle (Tugal et al., 1991). Synaptotagmin contains two cytoplasmic domains similar to the C2 region of protein kinase C (PKC) (Perin et al., 1990, 1991a,b; Wendland et al., 1991; Davletov and Südhof, 1993). C2 domains are thought to mediate calcium and lipid regulation of PKC and, therefore, may mediate the calcium-dependent process of synaptotagmin as well (Nishizuka, 1988; Lee and Bell, 1991). Whereas synaptotagmin $I$ is abundantly expressed in the nervous system, many members of the synaptotagmin family are expressed broadly throughout other non-neural tissues (Geppert et al., 1991; Wendland et al., 1991; Hilbush and Morgan, 1994; Mizuta et al., 1994; Ullrich et al., 1994; Li et al., 1995), and the precise function 
of synaptotagmin is not yet fully appreciated. Microinjection and genetic studies suggest a role in regulating synaptic transmission, either by stabilizing the docked state of vesicles or as a calcium sensor for the rapid release of neurotransmitter (Brose et al., 1992; Bommert et al., 1993; Elferink et al., 1993; DiAntonio and Schwarz, 1994; Geppert et al., 1994; Littleton et al., 1994). The association of synaptotagmin with the clathrin adaptor protein AP-2 suggests a role for synaptotagmin in recycling synaptic vesicle membrane and proteins (Zhang et al., 1994).

Recent studies have shown that synaptotagmin directly binds to syntaxin, a component of the receptor for the synaptic vesicle on the plasma membrane (Bennett et al., 1992). This binding is calcium-dependent, and the different members of the synaptotagmin family require different calcium concentrations to promote the binding (Li et al., 1995). It has been suggested that the binding of synaptotagmin I to syntaxin has a calcium dependence in the appropriate range to regulate neurotransmitter release. To understand better the interaction between synaptotagmin and syntaxin, we have studied the in vitro interactions using recombinant proteins. We have defined the binding sites of synaptotagmin on syntaxin. The data demonstrate that the calcium-dependent synaptotagmin-binding site overlaps the $\alpha$ SNAP- and VAMPbinding sites on the third helix of syntaxin (Kee et al., 1995).

\section{MATERIALS AND METHODS}

Materials. Restriction enzymes and DNA-modifying enzymes were purchased from New England BioLabs (Beverly, MA) and Boehringer Mannheim (Indianapolis, IN). Pfu DNA polymerase and pBluescript II $\mathrm{SK}(-)$ were from Stratagene (La Jolla, CA). Glutathione-agarose, thrombin, reagent-grade chemicals, and ultrapure-grade chemicals were obtained from Sigma (St. Louis, MO) and U.S. Biochemicals (Cleveland, $\mathrm{OH})$. Electrophoresis-grade reagents and gelatin were purchased from Bio-Rad (Richmond, CA). Prestained SDS-PAGE molecular weight standards were purchased from Gibco (Gaithersburg, MD). Horseradish peroxidase-conjugated secondary antibodies were obtained from Zymed (San Francisco, CA). The enhanced chemiluminescence (ECL) system and Sequenase kit were from Amersham (Arlington Heights, IL; peroxidase-secondary). Films were from Kodak (Rochester, NY) or Amersham (Hyperfilm). Nitrocellulose filters were from Schleicher \& Schuell (Keene, NH).

Construction of syntaxin $1 A 20$ and 21 deletion mutants. Recombinant plasmids encoding glutathione S-transferase (GST) linked by a thrombincleavage sequence to syntaxin 1a fragments 20 (amino acids 220-266) and 21 (amino acids 240-266) (Fig. 6) were constructed by cloning restriction enzyme-digested fragments of syntaxin after PCR into the expression vector pGEX-KG (Guan and Dixon, 1991). Pfu DNA polymerase was used for PCR. The recombinant plasmids were transformed into the AB1899 strain of Escherichia coli, and fusion proteins were expressed.

Purification of fusion proteins. The bacterial cells expressing GST fusion proteins of syntaxin 1a and synaptotagmin I were cultured in Superbroth (3.2\% bactotrypton, $2 \%$ yeast extract, and $85.6 \mathrm{~mm} \mathrm{NaCl}$, pH-adjusted to 7.0 with $\mathrm{NaOH}$ ) with $100 \mu \mathrm{g} / \mathrm{ml}$ ampicillin, and induced with 100 or 200 $\mu \mathrm{M}$ isopropyl- $\beta$-D-thiogalactopyranoside (or IPTG) for $5 \mathrm{hr}$. The cells were harvested, suspended in PBS containing $0.05 \%(\mathrm{v} / \mathrm{v})$ Tween 20,2 mM EDTA, $0.1 \%$ 2-mercaptoethanol, and $1 \mathrm{~mm}$ phenylmethylsulfonylfluoride (PMSF), and lysed by two passages through a French press. Cellular debris was removed by centrifugation at $10,000 \times g$ for $10 \mathrm{~min}$, and fusion protein was recovered from the supernatant by binding of the GST domain to glutathione-agarose beads equilibrated with PBST (PBS and $0.05 \%$ Tween 20 ) for $1 \mathrm{hr}$ at $4^{\circ} \mathrm{C}$. The beads were washed four times with PBST, and their bound protein was used for assays either immobilized on the GST beads or as a soluble protein after thrombin cleavage. Thrombin cleavage was carried out at room temperature for $1 \mathrm{hr}$ in 20 $\mathrm{mM}$ HEPES/KOH, pH 7.4, $150 \mathrm{mM} \mathrm{KCl}$, and $1 \mathrm{mM} \mathrm{CaCl}$, and the reaction was stopped by two treatments with $0.5 \mu \mathrm{l}$ of $1 \mathrm{M}$ PMSF at room temperature for $5 \mathrm{~min}$ each. The protein solution was centrifuged, and the supernatant was collected for in vitro binding assay. Protein concentrations were estimated by Coomassie blue staining of bands after SDSPAGE using bovine serum albumin as a standard.

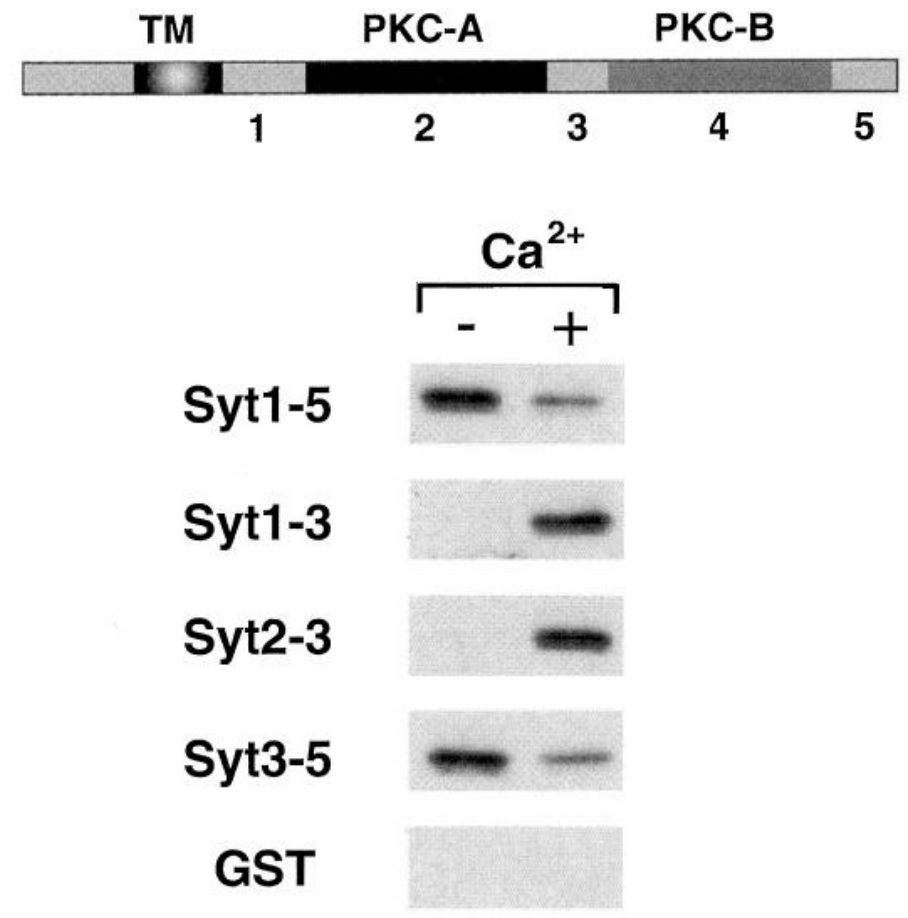

Figure 1. Calcium-dependent and -independent syntaxin binding to synaptotagmin I. A schematic diagram of synaptotagmin I is illustrated, and the domains used in the constructs for this study are illustrated below $(1-5)$. The location of the transmembrane domain $(T M)$ and the location of two cytoplasmic repeats homologous to the $\mathrm{C} 2$ regulatory domain of PKC (PKC-A and PKC-B) are indicated. The cytoplasmic fragments encompassing synaptotagmin (Syt1-5, Syt1-3, Syt2-3, and Syt3-5) were generated by expression in bacteria as GST fusion proteins and immobilized onto glutathione-agarose beads. Soluble whole cytoplasmic protein of Synla11 was tested for binding in the presence of 1 mM EGTA $(-)$ or $1 \mathrm{~mm}$ calcium (+). GST beads were used as a control for nonspecific binding.

In vitro binding assay. Typical binding reactions consisted of $0.3-2 \mu \mathrm{M}$ GST fusion proteins bound to glutathione-agarose beads and various amounts of soluble recombinant proteins in a total volume of $50 \mu \mathrm{l}$ in 20 mM HEPES/KOH, pH 7.4, $150 \mathrm{~mm} \mathrm{KCl,} 0.05 \%$ Tween $20,0.1 \%(\mathrm{w} / \mathrm{v})$ gelatin, and $5 \mu \mathrm{l}$ of $50 \%(\mathrm{v} / \mathrm{v})$ GST fusion protein on glutathione-agarose beads, and were incubated at $4^{\circ} \mathrm{C}$ for $1 \mathrm{hr}$. The levels of GST fusion proteins were monitored by Ponceau staining after binding reactions and transfer to nitrocellulose membrane.

For calcium-dependent and -independent binding reactions, $0.3 \mu \mathrm{M}$ synaptotagmin fragments were immobilized on glutathione-agarose beads, and $2 \mu \mathrm{M}$ soluble cytoplasmic domain of syntaxin was added in standard binding reaction conditions. EGTA ( $2 \mathrm{~mm}$ ) was used to remove free calcium in solution, and $1 \mathrm{~mm} \mathrm{CaCl}$ was used for calcium-dependent binding reactions. The bound syntaxin was visualized by ECL and quantitated by densitometry. In Figure 1, the pixel values for bound syntaxin to synaptotagmin fragments were 277 and 64 for Syt1-5, 0 and 262 for Syt $1-3,0$ and 257 for Syt $2-3,253$ and 67 for Syt $3-5$, and 0 and 0 for GST (from left to right).

Calcium specificity was demonstrated by substituting divalent cations, 1 mM CaCl $2,1 \mathrm{~mm} \mathrm{BaCl}, 1 \mathrm{~mm} \mathrm{SrCl}$, and $2 \mathrm{~mm} \mathrm{MgCl}_{2}$, and 2 mM EGTA was used for calcium-free reactions. In Figure $2 A$, the pixel values for bound syntaxin to synaptotagmin fragments were as follows: 275,158 , 192,185 , and 202 for Syt $1-5 ; 20,121,27,19$, and 13 for Syt $1-3 ; 26,232$, 30,28 , and 28 for Syt $2-3 ; 332,129,242,165$, and 162 for Syt $3-5$; and 4, $4,4,21$, and 17 for GST (from left to right). Calcium concentrations for binding of syntaxin to immobilized synaptotagmin fragments were titrated at 2 mM EGTA, and $0,1,10,50,100,200,400,600,1000 \mu \mathrm{M} \mathrm{CaCl}_{2}$. In Figure $2 B$, the pixel values were as follows: $522,391,341,310,291,281$, 135,237 , and 255 for Syt $1-5 ; 40,40,40,40,53,67,117,160,153$, and 422 for Syt $1-3 ; 40,40,40,40,40,47,55,61,120$, and 769 for Syt $2-3 ; 504,260$, $290,241,226,233,151,172,162$, and 325 for Syt3-5; and all 45 for GST (from left to right). 
A

\section{Syt1-5}

$$
\text { EGTA } \mathrm{Ca}^{2+} \mathrm{Ba}^{2+} \mathrm{Sr}^{2+} \mathrm{Mg}^{2+}
$$

\section{Syt1-3}

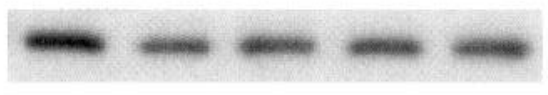

\section{Syt2-3}

\section{Syt3-5}

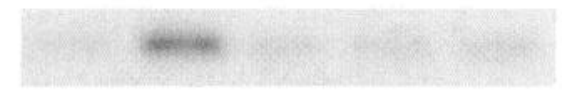

GST

B

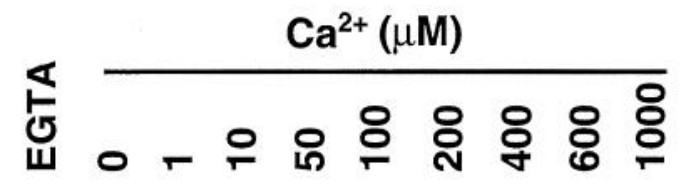

Syt1-5

Syt1-3

\section{Syt2-3}

\section{Syt3-5}

\section{GST}

Figure 2. Calcium specificity and concentration dependence of soluble syntaxin binding to synaptotagmin on beads. $A$, Calcium specificity for binding of the whole cytoplasmic domain of syntaxin, to synaptotagmin fragments (Syt1-5, Syt1-3, Syt2-3, and Syt3-5) immobilized onto beads. The binding reactions were done in the presence of $2 \mathrm{~mm} E G T A, 1 \mathrm{~mm}$

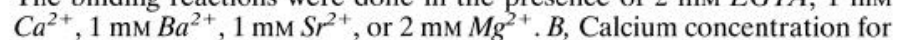
binding of soluble Syn1a11 to synaptotagmin I fragments. Binding was done in the presence of $2 \mathrm{~mm} E G T A$ or $0,1,10,50,100,200,400,600$, or $1000 \mu \mathrm{M} \mathrm{CaCl}_{2}$.

Another calcium-dependent reaction contained $0.3 \mu \mathrm{M}$ of the whole cytoplasmic domain of syntaxin, which was immobilized onto glutathioneagarose beads, and $2 \mu \mathrm{M}$ soluble whole cytoplasmic fragment of synaptotagmin was added for in vitro binding reaction. In Figure $3 A$, the pixel values of bound synaptotagmin were as follows: $83,366,81,84$, and 44 for Syn1a11; and 46, 25, 52, 23, 20, and 20 for GST (from left to right). In Figure $3 B$, the pixel values were as follows: 14, 5, 5, 5, 22, 137, 185, 204, and 385 for Syn1a11; and all 5 for GST (from left to right).

For localization of the synaptotagmin-binding domain on syntaxin, first $1 \mu \mathrm{M}$ of a synaptotagmin fragment containing the first C2 repeat, Syt2-3, was immobilized onto glutathione-agarose beads, and soluble syntaxin mutant proteins were added in the presence of $5 \mathrm{~mm}$ EGTA or $1 \mathrm{~mm}$ $\mathrm{CaCl}_{2}$. Protein concentrations of syntaxin $1 \mathrm{~A} 11,1 \mathrm{~A} 17$, and $1 \mathrm{~A} 13$ for calcium-dependent and -independent protein-protein interactions were titrated in the typical binding assay conditions with synaptotagmin fragments immobilized on beads. In Figure 4, the pixel values of syntaxin mutant bands were as follows: 20 and 20 for $1 \mathrm{~A} 6 ; 20$ and 30 for $1 \mathrm{~A} 13 ; 20$
A

\section{Syn1a11}

\section{EGTA $\mathrm{Ca}^{2+} \mathrm{Ba}^{2+} \mathrm{Sr}^{2+} \mathrm{Mg}^{2+}$}

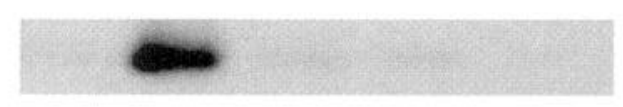

B

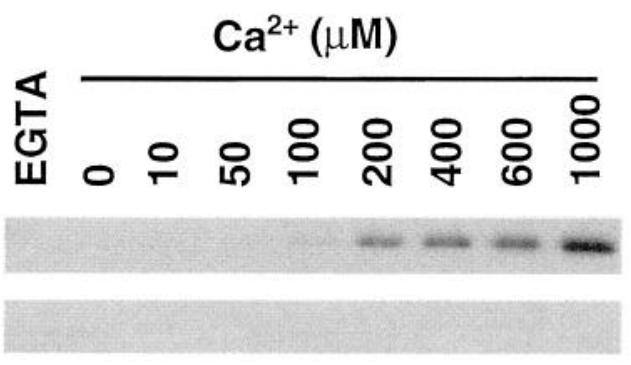

Figure 3. Calcium specificity and concentration dependence of soluble synaptotagmin binding to syntaxin on beads. $A$, Calcium specificity for binding of the soluble whole cytoplasmic domain of synaptotagmin (Syt1-5) to Syn1a11 on beads. Binding was conducted in the presence of

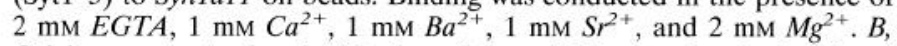
Calcium concentration for binding of the soluble cytoplasmic domain of synaptotagmin to SynIall. Binding reactions were performed in the presence of $2 \mathrm{~mm} E G T A$ or $0,10,50,100,200,400,600$, or $1000 \mu \mathrm{M} \mathrm{CaCl}_{2}$.

and 284 for $1 \mathrm{~A} 17$; and 63 and 474 for $1 \mathrm{~A} 11$ (from left to right). In Figure 5 , the pixel values of bound Syn1a11 were as follows: $0,21,49,136,215$, $7,8,16,49$, and 97 for Syt $1-5 ; 0,0,1,14,17,7,33,61,136$, and 230 for Syt $1-3 ; 0,0,0,17,34,10,50,136,266$, and 400 for Syt $2-3 ; 0,34,86,155$, $257,0,5,14,110$, and 256 for Syt $3-5$; and $0,0,0,0,0,0,0,0,0$, and 20 for GST (from left to right). The pixel values of bound Syn1a17 were as follows: $0,0,0,0,0,0,0,0,0$, and 6 for Syt $1-5 ; 0,0,0,0,0,0,4,16,46$,

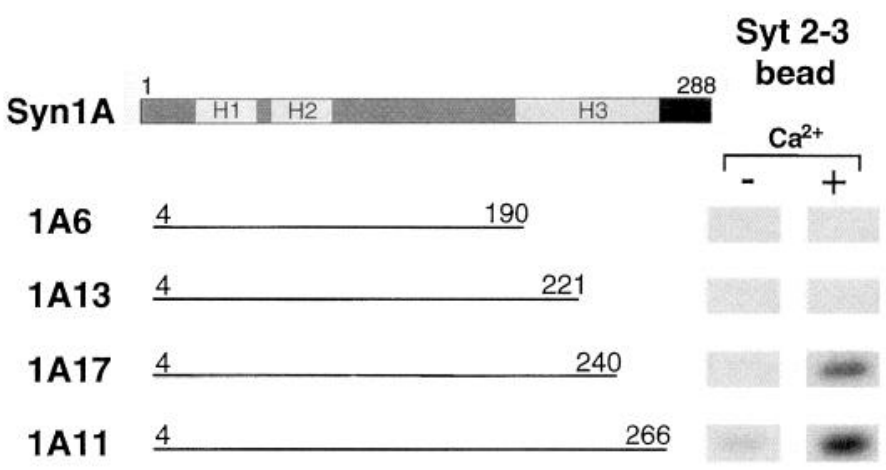

Figure 4. The calcium-dependent synaptotagmin-binding domain is localized in the middle of the third helix of syntaxin. A schematic diagram of the syntaxin 1a $(\operatorname{Syn} 1 A)$ protein is illustrated. The locations of three regions predicted to be in $\alpha$-helical conformation $(H 1, H 2$, and $H 3)$ and the membrane-anchoring region (black box of C-terminal region) are indicated. The extents of the deletion constructs are illustrated and numbered according to Bennett et al. (1992). Binding of soluble syntaxin fragments $(1 A 6,1 A 13,1 A 17$, and $1 A 11)$ to synaptotagmin fragment 2-3 (Syt 2-3) containing the first $\mathrm{C} 2$ repeat on the beads is illustrated. Binding was compared in the presence of 2 mM EGTA $(-)$ or $1 \mathrm{mM} \mathrm{Ca}^{2+}(+)$. 
EGTA

Syn1a11 $(\mu M)$
Syt1-5
Syt1-3
Syt2-3
Syt3-5
GST
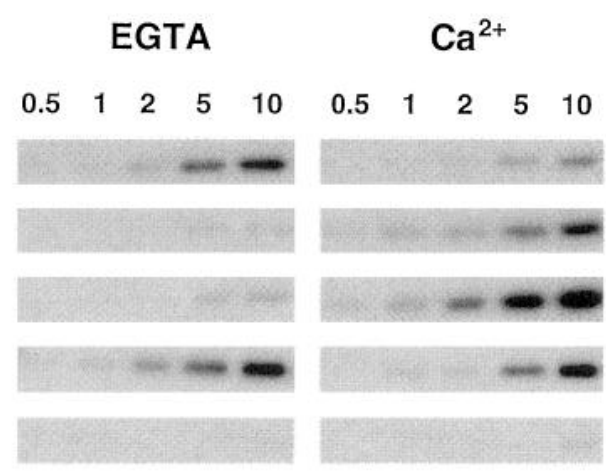

\section{Syn1a17 $(\mu \mathrm{M})$}

Syt1-5

Syt1-3

Syt2-3

Syt3-5

GST
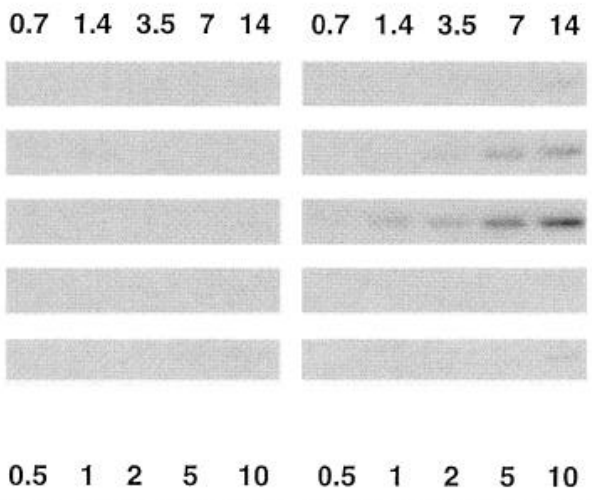

\section{5}

\section{$\begin{array}{lllll}0.5 & 1 & 2 & 5 & 10\end{array}$}

Syt1-5

Syt1-3

Syt2-3

Syt3-5

GST

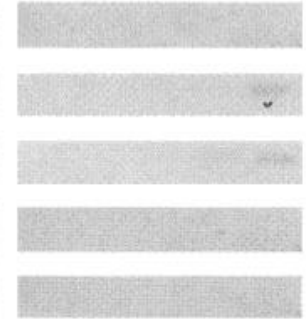

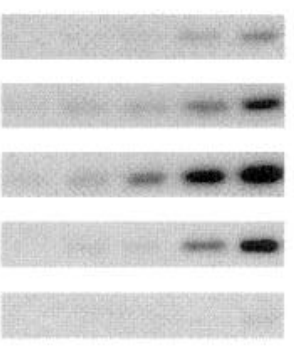

Figure 5. Titration of syntaxin fragments binding to synaptotagmin domains on beads. Different amounts of soluble thrombin-cleaved syntaxin fragments were added to each reaction in the presence of $5 \mathrm{~mm} E G T A$ or $1 \mathrm{mM} \mathrm{Ca}{ }^{2+}$. Syntaxin and synaptotagmin constructs are as defined in Figures 4 and 1, respectively.

and 63 for Syt1-3; 0, 0, 0, 0, 0, 7, 33, 55, 126, and 183 for Syt $2-3$; and all 0 for Syt 3-5 and GST. The pixel values of bound Syn1a13 were as follows: all 0 for Syn1-5; 0, 0, 0, 0, 0, 0, 0, 0, 8, and 30 for Syt $1-3 ; 0,0,0$, $0,0,0,0,0,9$, and 30 for Syt $2-3$; and all 0 for Syt $3-5$ and GST. Second, the calcium-dependent synaptotagmin-binding domain on syntaxin was determined using more C-terminal deletion mutants of syntaxin. GST fusion proteins $(0.3-1 \mu \mathrm{M})$ of syntaxin mutants were immobilized onto glutathione-agarose beads, and $2 \mu \mathrm{M}$ soluble whole cytoplasmic fragment of synaptotagmin was added in the presence of $1 \mathrm{~mm} \mathrm{CaCl}$. The pixel values of bound synaptotagmin were $171,145,182,727,511,584$, and 21 (from top to bottom).

SDS-PAGE and Western blotting. SDS-PAGE was performed by the method of Laemmli (1970). The stacking gel $\left(10 \times 90 \times 0.75 \mathrm{~mm}^{3}\right)$ contained $4.8 \%$ acrylamide and $0.2 \%$ bisacrylamide, and resolving gel (55 $\times 90 \times 0.75 \mathrm{~mm}^{3}$ ) contained 12.5 or $10 \%$ acrylamide and $0.2 \%$ bisacrylamide. Proteins resolved by SDS-PAGE were electrophoretically transferred to nitrocellulose paper in $384 \mathrm{~mm}$ glycine, $50 \mathrm{~mm}$ Tris base, and $20 \%$ methanol at $55 \mathrm{~V}$ for $48 \mathrm{~min}$ at $4^{\circ} \mathrm{C}$ (Towbin et al., 1979). The nitrocellulose filters were incubated with blocking buffer $[50 \mathrm{~mm}$ Trisbase, $\mathrm{pH} 8.0,150 \mathrm{~mm} \mathrm{NaCl}, 5 \%(\mathrm{w} / \mathrm{v})$ dried nonfat milk powder, and $0.1 \%$ Tween 20] for $20 \mathrm{~min}$ and then transferred to blocking buffer probed with the following antibodies for $2 \mathrm{hr}$ at room temperature or overnight at $4^{\circ} \mathrm{C}$ : HPC-1, a monoclonal antibody specific for syntaxin 1a (1:3000; Inoue et al., 1992), affinity-purified anti-synaptotagmin polyclonal antiserum (1: $5000)$, and anti- $\alpha$ SNAP antiserum (1:5000; Kee et al., 1995). The blots were washed three times for $5 \mathrm{~min}$ with blocking buffer and then incubated with peroxidase-conjugated secondary antibodies for $30 \mathrm{~min}$ at room temperature. The blots were again washed three times for $5 \mathrm{~min}$ each with blocking buffer and twice for 3 min each with PBS, processed with ECL reagents, and exposed to Amersham Hyperfilm or Kodak film.

\section{RESULTS}

\section{Calcium-dependent and -independent syntaxin binding to synaptotagmin}

To determine the functional roles and calcium-binding properties of the synaptic vesicle protein synaptotagmin I, calciumdependent and -independent protein-protein interactions between synaptotagmin I and syntaxin la were investigated. Bacterially expressed GST fusion proteins of the synaptotagmin fulllength cytoplasmic domain and deletion fragments were immobilized onto glutathione-agarose beads. The whole cytoplasmic domain of syntaxin 1a was prepared by expression in bacteria as a GST fusion protein, followed by purification by glutathioneagarose chromatography and thrombin cleavage. The soluble syntaxin protein was tested for binding to synaptotagmin fragments in the presence or absence of calcium as described in Materials and Methods. As shown in Figure 1, the syntaxin bound to the fulllength cytoplasmic fragment of synaptotagmin, Syt1-5 (amino acids 96-421), in the absence of calcium, and the level of binding was significantly reduced in the presence of calcium. Furthermore, the $\mathrm{C}$-terminal region of synaptotagmin containing the second $\mathrm{C} 2$ repeat, PKC-B (Syt3-5; amino acids 248-421), showed the same binding properties as the full-length cytoplasmic protein. On the contrary, binding of syntaxin to the N-terminal fragments of synaptotagmin containing the first $\mathrm{C} 2$ repeat (PKC-A), Syt1-3 (amino acids 96-265), and Syt2-3 (amino acids 130-265), was calcium-dependent.

The divalent cation selectivity for the interaction of syntaxin and synaptotagmin was evaluated using $2 \mathrm{~mm} \mathrm{EGTA,} 1 \mathrm{~mm} \mathrm{CaCl}_{2}$, $1 \mathrm{mM} \mathrm{BaCl}_{2}, 1 \mathrm{~mm} \mathrm{SrCl}$, and $2 \mathrm{mM} \mathrm{MgCl}_{2}$ (Fig. $2 A$ ). A calciumdependent decrease of the binding of soluble syntaxin to the full-length cytoplasmic fragment of synaptotagmin (Syt1-5) or the C-terminal fragment containing the second C2 repeat (Syt3-5) was consistently detected. The presence of barium, strontium, or magnesium in the reaction had relatively little effect on the binding compared with calcium ion at the same concentration. The binding of soluble syntaxin to the first C2-containing fragments (Syt 1-3 or Syt $2-3$ ) was strictly dependent on calcium and not affected by other ions.

The calcium concentrations required for protein-protein interactions between syntaxin and synaptotagmin were investigated (Fig. $2 B$ ). The decrease in binding of Syt $1-5$ and Syt $3-5$ occurred at relatively low concentrations of calcium, even at $1 \mu \mathrm{M} \mathrm{CaCl}_{2}$. In contrast, the binding of Syt $1-3$ and Syt2-3 was only enhanced at calcium concentration above $100 \mu \mathrm{M}$.

The soluble synaptotagmin cytoplasmic fragment (Syt1-5) was prepared as described in Materials and Methods. GST fusion protein encompassing the entire cytoplasmic domain of syntaxin was immobilized on the glutathione-agarose beads. As shown in Figure 3, binding of soluble synaptotagmin was calciumdependent, and barium, strontium, and magnesium were not effective in promoting this binding. Calcium titration revealed that the binding initiated at $\sim 100 \mu \mathrm{M}$ calcium. The binding of synaptotagmin to syntaxin was significantly increased at $1 \mathrm{~mm} \mathrm{CaCl}_{2}$, demonstrating that the half-maximal binding occurs at $>500 \mu \mathrm{M}$ $\mathrm{CaCl}_{2}$. 


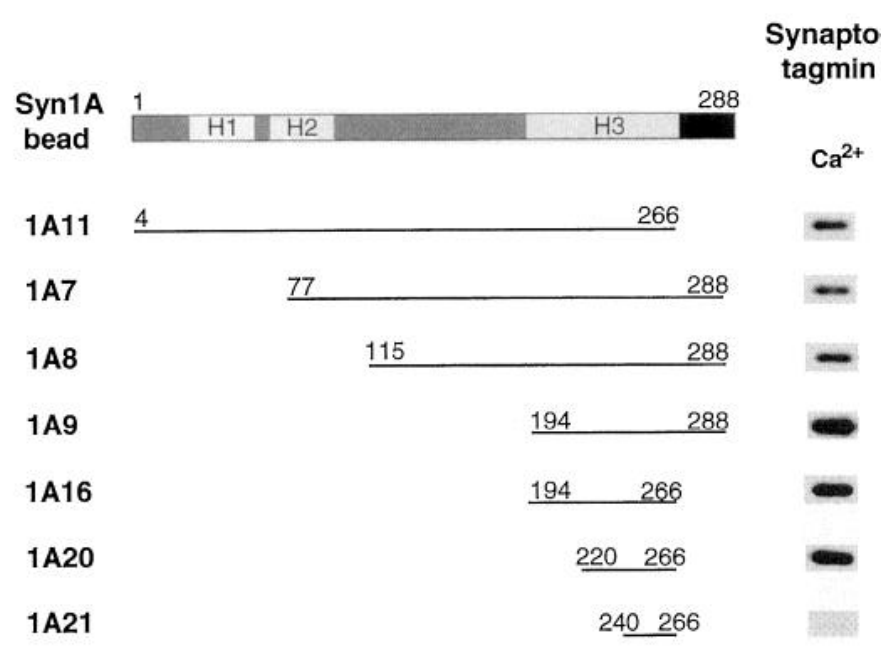

Figure 6. The calcium-dependent synaptotagmin-binding region on the syntaxin defined by deletion mutants of syntaxin. A schematic diagram of the Syn $1 A$ protein is illustrated. Soluble synaptotagmin protein containing the whole cytoplasmic domain was assayed for binding to syntaxin deletion constructs on beads in the presence of $1 \mathrm{mM} \mathrm{Ca}^{2+}$. Under these conditions, no binding was observed in the presence of EGTA.

\section{Localization of calcium-dependent and -independent synaptotagmin-binding domains on syntaxin}

The syntaxin domains required for binding of many components of the secretory apparatus are known (Chapman et al., 1994; Kee et al., 1995). A predicted helical domain of syntaxin ( $H 3$ domain in Fig. 4) that may interact with other proteins through the coiled-coil motif was required for binding of SNAP-25, $\alpha$ SNAP, VAMP, and n-sec1. To test the importance of this region in syntaxin-synaptotagmin interaction, a series of deletion mutants in the third helical domain (H3) was constructed. A synaptotagmin fragment containing the first $\mathrm{C} 2$ repeat (Syt2-3) was immobilized onto the glutathione-agarose beads, and soluble syntaxin deletion mutants were tested for binding in the absence and presence of calcium (Fig. 4). The bound proteins were detected by HPC-1, syntaxin 1a monoclonal antibody. The full-length cytoplasmic domain of syntaxin, 1A11, showed calcium-dependent binding to synaptotagmin, as did the $\mathrm{C}$-terminal deletion mutant 1A17. However, more C-terminal deletions of syntaxin (1A13 and 1A6) showed little or no calcium-dependent binding. These data indicate that a critical domain required for calcium-dependent binding of synaptotagmin is amino acids $222-240$ of $\mathrm{H} 3$ of syntaxin.

The protein concentrations for calcium-dependent proteinprotein interactions between these syntaxin deletion mutants and synaptotagmin fragments were titrated in the absence or presence of $1 \mathrm{~mm}$ calcium (Fig. 5). The soluble syntaxin deletion mutants were tested for their ability to bind to the various GST fusion constructs of synaptotagmin on the beads. The full-length cytoplasmic domain of syntaxin (Syn1a11) consistently showed a calcium-dependent decrease of binding to Syt $1-5$ and Syt $3-5$, and calcium-dependent binding to Syt1-3 and Syt2-3 at each of the different protein concentrations. However, C-terminal-deleted syntaxin 1A17 (Syn1a17) did not bind to the full-length cytoplasmic domain of synaptotagmin in the absence or presence of calcium, but bound to Syt 1-3 and Syt2-3 only in the presence of calcium. This calcium-dependent binding of Syn1a17 also showed approximately three- to fourfold lower affinity than the binding of full-length syntaxin. Further deletion of the H3 domain, syntaxin
$1 \mathrm{~A} 13$, showed only very little calcium-dependent binding to Syt1-3 and Syt2-3. These data demonstrate that the C-terminal cytoplasmic region of the predicted helical domain of syntaxin (amino acids 241-266) is required for both calcium-independent and calcium-dependent binding to synaptotagmin.

Syntaxin N-terminal deletion mutants were prepared as GST fusion proteins, attached to glutathione beads, and analyzed for calcium-dependent binding of soluble full-length cytoplasmic synaptotagmin, Syt1-5 (Fig. 6). Deletion of N-terminal amino acids 1-219 and C-terminal amino acids 267-288 (transmembrane domain) in syntaxin did not affect the calcium-dependent synaptotagmin-binding activity. Deletion of amino acids 220-239 in syntaxin resulted in abolishment of calcium-dependent synaptotagmin-binding activity, indicating that this small region is required for the calcium-dependent protein-protein interactions with synaptotagmin. These data confirm the calcium-dependent synaptotagmin-binding region of syntaxin shown by $\mathrm{C}$-terminal deletion mutant study and define the calcium-dependent binding region with high affinity as amino acids 220-266 (Fig. 4).

\section{DISCUSSION}

In this study we have investigated the protein-protein interactions of synaptotagmin and syntaxin, two critical components of the synaptic transmission machinery. Some of the protein-protein interactions were dependent on which component of the binding reaction was immobilized onto glutathione-agarose beads as a GST fusion protein. For example, when the full-length cytoplasmic domain of synaptotagmin was immobilized to the bead, the binding of the soluble syntaxin full-length cytoplasmic domain was calcium-independent, and even reduced in efficiency in the presence of calcium. In contrast, when syntaxin was immobilized on the bead, the binding of the soluble full-length cytoplasmic domain of synaptotagmin was calcium-dependent. These data may be attributable to different protein conformations that could be favored in a conformationally restrained immobilized state. Alternatively, when the first $\mathrm{C} 2$ domain is closer to the immobilization matrix than the second C2 domain, as is the case in the GST fusion protein of the Syt $1-5$ construct, steric hindrance may result in a dominance of the second $\mathrm{C} 2$ domain. The data highlight the necessity to investigate protein-protein interactions with components in both the immobilized and the soluble states for general conclusions to be made. It is also possible that multiple conformations of the synaptotagmin protein exist and that different states are favored in the immobilized and soluble forms. Physiological regulation, possibly via phosphorylation or lipid binding, may interconvert these conformations.

All of the data are consistent with the calcium-dependent binding of syntaxin to the first $\mathrm{C} 2$ domain of synaptotagmin. Although we were not able to define precisely the calcium concentration necessary for half-maximal binding, it is likely to be in the several hundred micromolar range. This binding was specific for calcium ions and is either not supported or requires higher concentrations of other ions including barium, strontium, or magnesium. These properties are similar to those thought to be necessary for the physiological release of neurotransmitter.

Syntaxin 1a is a component of the receptor for synaptic vesicles on the plasma membrane and is known to interact with many of the critical proteins involved in neurotransmitter release. The binding sites on syntaxin for many of these proteins have been mapped in detail (Calakos et al., 1994; Chapman et al., 1994; Hayashi et al., 1994; Pevsner et al., 1994; Kee et al., 1995). The 
minimal regions of syntaxin required for the binding of $n$-sec1 (amino acids 4-240), SNAP-25 (amino acids 191-221), $\alpha$ SNAP (amino acids 191-240), and VAMP (amino acids 191-266) are all located in or contain the third predicted helical domain, H3. Here we demonstrated that amino acids $220-266$ of syntaxin are sufficient for the calcium-dependent binding of synaptotagmin. These data are consistent with the previous observation that as $\alpha$ SNAP is added to the complex of VAMP, SNAP-25, syntaxin, and synaptotagmin, synaptotagmin is displaced by $\alpha$ SNAP (Söllner et al., 1993a). Synaptotagmin does not bind to VAMP or SNAP-25 (data not shown) and, therefore, these data suggest that $\alpha$ SNAP and synaptotagmin may occupy the same or overlapping binding sites on syntaxin within the docking complex.

What might be the physiological consequence of the calciumdependent binding of synaptotagmin to the H3 domain of syntaxin? If one assumes that the calcium-regulated binding is, in fact, a physiologically important event, there are several possibilities for the function of this interaction. Perhaps the most exciting possibility is that calcium influx promotes the binding of synaptotagmin and syntaxin, and that this interaction leads to membrane fusion and neurotransmitter release. At this time it is difficult to understand mechanically how this regulated binding would be the final step in secretion. It is also unlikely that the binding would occur rapidly enough to fit the time requirements of synaptic transmission. It may be the case that vesicle docking is regulated by calcium in part through the binding of synaptotagmin to syntaxin. Perhaps an initial influx of calcium would promote the binding of synaptotagmin and syntaxin, mediated through the first C2 domain of synaptotagmin. 'Then, a second calcium signal could result in dissociation of synaptotagmin from the syntaxin complex, pcrhaps, mediated through the second $\mathrm{C} 2$ domain. The dissociation would then allow the interaction of $\alpha$ SNAP with the syntaxin complex and the progression through the biochemical pathway leading to secretion. Alternately, synaptotagmin might associate with syntaxin after dissociation of the $\alpha$ SNAP- and NSFcontaining $20 \mathrm{~S}$ particle acting as a break in the fusion process (Südhof, 1995). In this situation, perhaps calcium-triggered dissociation would lead to membrane fusion.

Because synaptotagmin is known to associate with the clathrin adaptor protein AP-2, and is likely to be important for the endocytotic process, calcium may play a role in this stage of the vesicle-trafficking pathway in an as yet unknown way (Zhang et al., 1994). Alternatively, there is little direct evidence that the $\mathrm{C} 2$ domain interaction with calcium is critical for the synaptic vesicle life cycle. The presence of many synaptotagmins in cells that are not known to have calcium-dependent mechanisms of secretion or recycling supports the idea that the synaptotagmins play a role in constitutive vesicle trafficking. Thus, although our appreciation of the mechanisms of synaptic transmission has advanced greatly in the last several years, further study is needed to understand the biochemical mechanisms that govern this process.

\section{REFERENCES}

Bennett MK, Scheller RH (1994) A molecular description of synaptic vesicle membrane trafficking. Annu Rev Biochem 63:63-100.

Bennett MK, Calakos N, Kreiner T, Scheller RII (1992) Synaptic vesicle membrane proteins interact to form a multimeric complex. J Cell Biol 116:761-775

Bommert K, Charlton MP, DeBello WM, Chin GJ, Bctz H, Augustine GJ (1993) Inhibition of neurotransmitter release by $\mathrm{C} 2$-domain peptides implicates synaptotagmin in exocytosis. Nature 363:163-165.

Brose N, Pctrenko AG, Südhof TC, Jahn R (1992) Synaptotagmin: a calcium sensor on the synaptic vesicle surface. Science 256:1021-1025.
Calakos N, Bennett MK, Peterson KE, Scheller RH (1994) Proteinprotein interactions contributing to the specificity of intracellular vesicular trafficking. Science 263:1146-1149.

Chapman ER, An S, Barton N, Jahn R (1994) SNAP-25, a t-SNARE which binds to both syntaxin and synaptobrevin via domains that may form coiled coils. J Biol Chem 269:27427-27432.

Davletov BA, Südhof TC (1993) A single C2 domain from synaplotagmin I is sufficient for high affinity calcium/phospholipid binding. J Biol Chem 268:26386-26390.

DiAntonio A, Schwarz IL (1994) 'The effect on synaptic physiology of synaptotagmin mutations in Drosophila. Neuron 12:909-920.

Elferink LA, Peterson MR, Scheller RH (1993) A role for synaptotagmin (p65) in regulated exocytosis. Cell 72:153-159.

Geppert M, Archer BT, Südhof TC (1991) Synaptotagmin II: a novel differentially distributed form of synaptotagmin. J Biol Chem 266: $13548-13552$

Geppert M, Goda Y, Hammer RE, Li C, Rosahl TW, Stevens CF, Südhof TC (1994) Synaptotagmin I: a major calcium scnsor for transmitter release at a central synapse. Cell 79:717-727.

Guan KL, Dixon JE (1991) Eukaryotic proteins expressed in Escherichia coli: an improved thrombin cleavage and purification procedure of fusion proteins with glutathione S-transferase. Anal Biochem 192:262-267.

Hayashi T, McMahon H, Yamasaki S, Binz T, Hata $Y$, Südhof TC, Nicmann H (1994) Synaptic vesicle membranc fusion complex: action of clostridial neurotoxins on assembly. EMBO J 13:50151-5061.

Hilbush BS, Morgan JI (1994) A third synaptotagmin gene. Syt3, in the mousc. Proc Natl Acad Sci USA 91:8195-8199.

Inoue A, Akagawa K (1992) Neuron-specific antigen HPC-1 from bovine brain reveals strong homology to epimorphin, an essential factor involved in epithelial morphogenesis; identification of a novel protein family. Biochem Biophys Res Commun 187:1144-1150.

Inoue A, Obata K, Akagawa K (1992) Cloning and sequence analysis of cDNA for a neuronal cell membranc antigen, HPC-1. J Biol Chem 267:10613-10619

Kee Y, Lin RC, Hsu S-C, Scheller RH (1995) Distinct domains of syntaxin are required for synaptic vesicle fusion complex formation and dissociation. Neuron 14:991-998.

Laemmli UK (1970) Cleavage of structural proteins during the assembly of the head of bacteriophage T4. Nature 227:680 -685.

l.ee M-H, Bell RM (1991) Mechanism of protein kinase $\mathrm{C}$ activation by phosphatidylinositol 4,5-bisphosphate. Biochemistry 30:1041-1049.

Li C, Ullrich B, Zhang JZ, Anderson RGW, Brose N, Südhof TC (1995) $\mathrm{Ca}^{2+}$-dependent and -independent activities of neural and non-neural synaptotagmins. Nature 375:594-599.

Littleton JT, Stern M, Perin M, Bellen HJ (1994) Calcium dependence of neurotransmitter release and rate of spontancous vesicle fusions are altered in Drosophila synaptotagmin mutants. Proc Natl Acad Sci USA 91:10888-10892.

Matthew WD, Tsavaler L, Reichardt LF (1981) Identification of a synaptic vesicle-specific membrane protein with a wide distribution in neuronal and neurosecretory tissue. J Cell Biol 91:257-269.

Mizuta M, Inagaki N, Nemoto Y, Matsukura S, Takahashi M, Scino S (1994) Synaptotagmin III is a novel isoform of rat synaptotagmin expressed in endocrine and neuronal cells. J Biol Chem 269:1167511678.

Nishizuka Y (1988) The molecular heterogencity of protein kinase $C$ and its implications for cellular regulation. Nature 334:661-605.

Oyler GA, Higgins GA, Hart RA, Battenberg E, Billingsley M, Bloom FE, Wilson MC (1989) The identification of a novel synaptosomalassociated protein, SNAP-25, differentially expressed by neuronal subpopulations. J Cell Biol 109:3039-3052.

Perin MS, Fried VA, Mignery GA, Jahn R, Südhof TC (1990) Phospholipid binding by a synaptic vesicle protein homologous to the regulatory region of protein kinase C. Nature 345:260-263.

Perin MS, Johnston PA, Özcelik T, Jahn R, Francke U, Südhof TC (1991a) Structural and functional conservation of synaptotagmin (p65) in Drosophila and humans. J Biol Chem 266:615-622.

Pcrin MS, Brosc N, Jahn R, Südhof TC (1991b) Domain structurc of synaptotagmin (p65). J Biol Chem 266:623-629.

Pevsner J, Hsu S-C, Scheller RH (1994) n-Secl: a neural-specific syntaxin-binding protein. Proc Natl Acad Sci USA 91:1445-1449.

Scheller RH (1995) Membrane trafficking in the presynaptic nerve terminal. Neuron 14:893-897.

Søgaard M, Tani K, Ye RR, Geromanos S, Tempst P, Kirchhausen T, Rothman JE, Söllner $T$ (1994) A rab protein is required for the as- 
sembly of SNARE complexes in the docking of transport vesicles. Cell 78:937-948.

Söllner T, Bennett MK, Whiteheart SW, Scheller RH, Rothman JE (1993a) A protein assembly-disassembly pathway in vitro that may correspond to sequential steps of vesicle docking, activation, and fusion. Cell 75:409-418.

Söllner 'I, Whiteheart SW, Brunner M, Erdjument-Bromage H, Geromanos S, Tempst P, Rothman JE (1993b) SNAP receptors implicated in vesicle targeting and fusion. Nature 362:318-324.

Südhof TC (1995) The synaptic vesicle cycle: a cascade of protein-protein interactions. Nature 375:645-653.

Towbin H, Staehelin T, Gordon J (1979) Flectrophoretic transfer of proteins from polyacrylamide gels to nitrocellulose sheets: procedures and some applications. Proc Natl Acad Sci USA 76:4350-4354.
Tugal HB, Leeuwen Fv Apps DK, Haywood J, Phillips JII (1991) Glycosylation and transmembrane topography of bovine chromaffin granule p65. Biochem J 279:699-703.

Ullrich B, Li C, Zhang JZ, McMahon H, Anderson RGW, Geppert M, Südhof TC (1994) Functional properties of multiple synaptotagmins in brain. Neuron 13:1281-1291.

Wendland B, Miller KG, Schilling J, Scheller RH (1991) Differential expression of the p65 gene family. Neuron 6:993-1007.

Wilson DW, Whiteheart SW, Wiedmann M, Brunner M, Rothman JE (1992) A multisubunit particle implicated in membrane fusion. J Cell Biol 117:531-538.

Zhang JZ, Davletov BA, Südhof TC, Anderson RGW (1994) Synaptotagmin $I$ is a high affinity receptor for clathrin AP-2: implications for membrane recycling. Cell 78:751-760. 